\title{
Potret kenakalan remaja dalam novel dilan dia adalah dilanku karya pidi baiq
}

\author{
Diski Junaidi Putra a, ${ }^{1}$, Yenni Hayati ${ }^{b, 2}$ \\ ${ }^{\text {a,b }}$ Program Studi Sastra Indonesia, Fakultas Bahasa dan Seni, Universitas Negeri Padang ${ }^{\text {I }}$ \\ diskijunaidi@gmail.com ${ }^{I^{*}}$; $^{2}$ yennihayati69@gmail.com \\ *korespondensi penulis
}

\begin{tabular}{ll}
\hline Informasi artikel & \\
\hline Sejarah artikel: & \\
Diterima & $:$ I7 Februari 2020 \\
Revisi & $:$ I9 April 2020 \\
Dipublikasikan & $:$ 30 April 2020 \\
\hline
\end{tabular}
\begin{abstract}
ABSTRAK
Penelitian ini bertujuan untuk mendeskripsikan kenakalan remaja baik dari segi bentuk, penyebab, dan dampak dari kenakalan yang dilakukan oleh remaja yang terdapat dalam novel Dilan Dia adalah Dilanku karya Pidi Baiq. Jenis penelitian ini adalah penelitian kualitatif dengan menggunakan metode deskritif dengan data yang berbentuk kata, frasa, klausa, atau kalimat yang mengindikasikan permasalahan kehidupan remaja dalam novel tersebut. Hasil penelitian ini membuktikan bahwa novel tersebut memperlihatkan kenakala remaja dan digambarkan tidak jauh berbeda dengan realita kehidupan remaja sekarang ini. Berdasarkan analisis data, kenakalan remaja yang terdapat dalam novel ditinjau dari (I) bentuk kenakalan remaja berupa kenakalan yang menimbulkan korban fisik, kenakalan yang menimbulkan korban materi, kenakalan sosial yang tidak menimbulkan korban, kenakalan yang melawan status; (2) penyebab kenakalan remaja berupa pembawaan bersifat negatif yang mengarah ke kerusakan, kurangnya kontrol diri dan persepsi sosial, ketidakmampuan untuk beradaptasi dengan perubahan lingkungan, kurangnya hobi kreatif atau hobi yang sehat, pengawasan kurang efektif dalam pembinaan, kurangnya pemahaman remaja dari lingkungan remaja, dan ketidaktahuan keluarga dalam menangani masalah remaja; (3) dampak kenakalan remaja berupa bagi remaja itu sendiri, bagi keluarga, dan bagi masyarakat.
\end{abstract}

Kata kunci:

remaja

kenakalan literatur

Key word: juvenile delinquents literature

\section{ABSTRACT}

This study aims to describe juvenile delinquency in terms of the form, causes, and effects of delinquency carried out by adolescents contained in the novel Dilan Dia adalah Dilanku by Pidi Baiq. This type of research is a qualitative study using descriptive methods with data in the form of words, phrases, clauses, or sentences that indicate the problems of adolescent life in the novel. The results of this study prove that the novel shows juvenile delinquency and is depicted not much different from the reality of adolescent life today. Based on data analysis, juvenile delinquency contained in the novel is reviewed from (I) the form of juvenile delinquency in the form of delinquency that causes physical casualties, delinquency that results in material casualties, social delinquency that does not cause victims, delinquency which is against status; (2) the causes of juvenile delinquency in the form of negative nature that leads to damage, lack of selfcontrol and social perception, inability to adapt to environmental changes, lack of creative hobbies or healthy hobbies, less effective supervision in coaching, lack of understanding of adolescents from the environment of adolescents, and family ignorance in dealing with adolescent problems; (3) the impact of juvenile delinquency in the form of adolescents themselves, for families, and for society.

Copyright (C) 2020 Universitas Ahmad Dahlan. All Right Reserved

\section{Pendahuluan}

Remaja sebagai salah satu bagian terpenting dari masyarakat yang mengalami runtutan perubahan dari masa kanak-kanak menuju masa dewasa. Pada masa ini, remaja mengalami banyak perubahan baik ditinjau dari segi fisik maupun psikologis. Secara psikologis, perubahan yang dialami oleh remaja kerap menimbulkan emosional yang berlebihan tanpa sebab apapun atau dengan alasan yang jelas. Sesuai dengan pendapat Hurlock (I99I) tentang terjadinya perubahan seperti fisik, psikologis, dan sosial di masa remaja. Secara fisik, perubahan yang dialami remaja seperti yang terjadi pada bentuk tubuh dan organ vital lainnya. Sedangkan secara psikologis, perubahan terjadi karena adanya pola 
kematangan emosi pada remaja dan perubahan dari lingkungan sosial yang ikut andil dalam proses interaksi remaja itu sendiri. Oleh karena itu, remaja sering menjadi sorotan bagi masyarakat karena perspektif dan sudut pandang mengenai keadaan remaja.

Masa remaja adalah masa dimana beralihnya perilaku seseorang dari kanak-kanak menjadi dewasa, atau bisa dikatakan masa remaja sebagai masa transisi. Pada masa ini, remaja yang mengalami peralihan sedang mencari pola hidup yang harus sesuai dengan apa yang diinginkannya. Namun dalam pencarian pola hidup, terkadang mereka sering melakukan dengan cara atau metoda yang salah. Jarang ditemukan remaja yang mencari jati diri dengan baik dan benar, semisalnya dengan kegiatan yang kreatif, berguna, atau hal lainnya yang bisa dianggap benar. Mirisnya, remaja cenderung melakukan suatu kesalahan tersebut secara berulang kali karena telah menjadi sebuah kegaliban. Hal ini disebabkan oleh faktor lingkungan dengan pembawaan negatif sehingga menciptakan pengaruh terhadap remaja dengan ketidakadanya kegiatan yang kreatif atau hobi yang sehat. Sebagaimana yang diketahui, bahwa masa remaja adalah masa yang rawan, jiwanya masih stabil, sangat mudah terpengaruh, atau terbawa arus dalam proses pencarian identitas diri. Pada proses pencarian identitas diri, dapat dilihat bahwa remaja melakukan berbagai adaptasi dengan lingkungan dan hal inilah yang memicu pertentangan dalam diri individu remaja itu sendiri. Dengan adanya pertentangan tersebut, remaja menjadi pribadi yang sangat mudah terpengaruhi atau terbawa oleh perbuatan yang mengandung unsur negatif atau timbulnya suatu kenakalan bagi remaja tersebut.

Dewasa ini, eksistensi remaja semakin mengkhawatirkan para orangtua dan juga masyarakat, sebab banyaknya bentuk kenakalan remaja yang diakibatkan perkembangan zaman dan juga teknologi yang semakin pesat. Kenakalan remaja dapat diartikan sebagai suatu keadaan dalam kehidupan sosial yang kurang menyenangkan karena dipengaruhi oleh lingkungan buruk. Ada masalah kenakalan remaja yang dikategorikan ke dalam hal yang bersentuhan dengan material atau kebendaan dan ada pula yang dikategorikan sebagai kenakalan yang menyinggung pada persoalan psikologi. Persoalan tersebut seperti tercemarnya nama baik seseorang, martabat seseorang, harga diri, dan ada pula yang mengkaitkan dengan kehidupan sosial. Jensen (dalam Sarwono: 2012) mengemukakan bentuk kenakalan remaja yang terbagi atas empat, yaitu (I) kenakalan yang menimbulkan korban fisik; (2) kenakalan yang menimbulkan korban materi; (3) kenakalan sosial yang tidak menimbulkan korban; dan (4) kenakalan yang melawan status. Dengan demikian, kenakalan remaja dengan aneka ragamnya menjadi tanggapan bagi masyarakat karena persoalannya cenderung menyita perhatian.

Di balik beragamnya bentuk kenakalan remaja, ada cukup banyak faktor yang mendorong remaja dalam melakukan suatu perbuatan menyimpang dari aturan yang ada. Seiring berkembangnya seorang anak, kenakalan remaja menjadi hal yang perlu diwaspadai dan lebih diperhatikan karena seorang anak cenderung melakukan kesalahan yang tidak lain dengan sebuah kenakalan. Selama kenakalan tersebut masih pada tingkat kewajaran, saat itu juga peran orangtua sangat perlu dalam mendampingi didikan seorang anak, terlebih lagi remaja sangat diprioritaskan dalam penanaman nilai dan norma. Jika orangtua telah mendidik, mengarahkan, ataupun membimbing, ada kemungkinan besar remaja melahirkan suatu pertimbangan dalam melakukan tindakan kenakalan. Akan tetapi, penyebab kenakalan remaja tidak hanya berasal dari ruanglingkup keluarga saja, namun ada beberapa faktor yang mempengaruhi remaja bertindak kenakalan tersebut. Seperti yang diungkapkan oleh B. Simadjuntak (dalam Jamiluddin: 2017) bahwa faktor yang melatarbelakangi penyebab kenakalan remaja ada dua, yakni faktor internal dan faktor eksternal.

Faktor internal yang mencakup cacat keturunan yang bersifat biologis-psikologis, pembawaan negatif yang mengarah perbuatan nakal, ketidak seimbangan pemenuhan kebutuhan pokok dengan keinginan, lemahnya kontrol diri dan persepsi sosial, ketidakmampuan penyesuaian diri terhadap lingkungan, dan tidak adanya kegemaran yang lebih kreatif. Sementara itu, faktor eksternal yang mencakup rasa cinta dari orangtua dan lingkungan, pendidikan yang kurang mampu menanamkan bertingkah laku, pengawasan yang kurang efektif dalam pembinaan; kurangnya pemahaman terhadap remaja, kurangnya sarana penyaluran waktu senggang, dan ketidaktahuan keluarga dalam menangani masalah remaja. Dengan kedua faktor tersebut, remaja dengan mudahnya terseret dalam lingkungan yang buruk (Jamiluddin: 2017).

Sebagian besar dari remaja, lebih sering bertindak tanpa memprioritaskan apa yang menjadi tujuan, mereka lebih menunjukan identitas dirinya kepada sosial. Di samping itu, ada sebagian dari mereka yang memiliki tujuan dengan berbagai resiko yang sudah dipertimbangkan. Banyak dampak negatif yang timbul akibat kenakalan remaja, dampak tersebut melibatkan diri remaja itu sendiri, keluarga, ataupun masyarakat (Sumara dkk: 20I7). Terkadang, remaja yang tahu akan dampak dari kenakalan yang dilakukan, justru cenderung 
melakukan lagi kenakalan yang sama. Dengan alasan balas dendam atau telah menjadi suatu kegaliban bagi remaja tersebut. Terlebih pada apa yang dilakukan remaja terssebut tidak bisa dikatakan sebagai suatu kenakalan atau suatu kesalahan yang wajar karena banyak ditemukan kejadian-kejadian yang berkenaan dengan kriminalitas atau tindakan yang bersifat brutal yang disebabkan oleh remaja. Sebagaimana yang dilihat, bahwa kebanyakan remaja sering mengabaikan sosial sehingga mereka melakukan tindakan atas dasar yang bersifat kesenangan. Bisa dikatakan, bahwa kenakalan remaja sebagai suatu fenomena dimana diri individu remaja bertentangan dengan norma yang ada sehingga melakukan suatu tindakan yang menyimpang.

Remaja dengan kehidupan yang diselingi problema-problema yang dihadapi pantas menjadi sorotan publik karena persoalannya menyita perhatian. Terkhusus pada pengarang sebuah karya sastra yang kerap menjadikan kehidupan remaja sebagai objek dalam karya-karyanya. Apalagi, remaja menjadi sasaran pengarang dalam memasarkan karya di tengah publik. Intinya, eksistensi remaja menjadi suatu ketertarikan bagi pengarang dalam menciptakan karyanya dan membincangkan tentang kehidupan remaja dalam dunia sastra. Faktanya, banyak sekali ditemukan karya sastra berupa novel populer yang berbau remaja, seperti Dyan Nuraindya dengan novel yang berjudul Dealova, Erisca Febriani dengan novel Serendipity, Rio Wahyu Cakraningrat dengan novel Diary Lara dan masih banyak pengarang lain yang menjadikan remaja sebagai topik dengan menyelipkan beberapa problema yang dihadapi remaja, seperti kenakalan remaja.

Terciptanya karya sastra sebagai hasil kreatif pengarang yang menyuguhkan berbagai persoalan yang terjadi di tengah masyarakat. Sebagaimana yang diungkapkan Wellek dan Warren (2014) bahwa karya sastra menyuguhkan kehidupan yang sebagian besar dari realitas masyarakat. Maksudnya, karya sastra lebih mewakili kehidupan masyarakat walaupun faktanya hanya rekaan pengarang, kehidupan dalam karya sastra dapat dikatakan tidak lain dari sebuah tiruan (mimesis) yang dirangkai beralaskan kehidupan realitas. Hal ini senada dengan pendapat Damono (2002) bahwa karya sastra menyajikan gambaran kehidupan yang merupakan rekaan pengarang. Melaui karya sastra, persoalan yang ditemui dalam kehidupan akan diketahui dan dapat dipahami oleh pembaca. Oleh karena itu, sastra memiliki suatu fungsi sebagai cerminan dari realitas.

Salah satu karya sastra yang dapat mendeskripsikan sosial masyarakat yang terjadi secara detail dan realistis adalah novel. Novel sebagai hasil tuangan pemikiran pengarang dengan berbagai ide kretaifnya agar membentuk suatu rangkap kalimat yang berisikan persoalan yang terjadi di tengah masyarakat. Wellek dan Warren (20I4) Novel bersifat relaistis, yang berkembang dari dokomen-dokumen. Secara sitilistika, novel mementingkan detail, dan bersifat mimesis dalam arti sempit. Hal menarik lainnya, realitas yang lebih tinggi dan psikologi yang lebih mendalam dirangkul menjadi satu dalam sebuah novel. Selain itu, novel lebih memperlihatkan atau mencerminkan tokoh yang berangkat dari realitas sosial atau tokoh dengan gambaran yang nyata. Oleh sebab itu, novel dapat menyampaikan berbagai dialog yang mampu menggerakkan hati pembaca atau penikmatnya.

Lewat novel, pengarang mengajak pembacanya untuk mengeksplorasi dan dijadikan media penemuan diri. Maksudnya, pengarang menulis sebuah novel dengan tujuan ingin menyampaikan sebuah pesan tentang pandangan kehidupan manusia serta pemahaman melalui uraian cerita dengan aksi tokoh dalam novel tersebut, tidak hanya sekedar untuk menimbulkan rasa senang pembaca atau penikmat karyanya. Namun, pada dasarnya pengarang meciptakan novel untuk dinikmati oleh pembaca atau penikmatnya. Dalam artian, pembaca atau penikmatnya merupakan masyarakat yang berada di lingkungan yang melingkupinya. Bisa dikatakan bahwa, eksistensi masyarakat merupakan titik tumpul keberhasilan pengarang dalam sebuah karyanya. Terutama pada kalangan remaja yang menjadi pusat perhatian pegarang untuk menjadikan kehidupan remaja menjadi objek dalam karyakaryanya.

Salah satu novel yang berisikan cerita yang berkenaan dengan kehidupan remaja adalah novel Dilan Dia adalah Dilanku karya Pidi Baiq. Novel Dilan Dia adalah Dialnku menjadi salah satu kesuksesan bagi Pidi Baiq selama berkarir. Seniman multitalenta tersebut dikenal para pencinta karya sastra khusunya bergenre humor. Kebanyakan karya yang dilahirkan oleh pemikiran seniman tersebut menggelitik hati penikmat sastra atau pembaca. Seperti novel ini yang menggambarkan kisah percintaan yang tidak asing dari realitas kehidupan pada sekarang ini, terkhusus pada remaja. Dengan selipan problema-probelma yang dihadang oleh remaja sehingga menimbulkan pertentangan dalam diri tokoh yang diceritakan dalam novel tersebut.

Novel ini terdiri dari dua novel, yakni Dilan Dia adalah Dilanku Tahun 1990 dan Dilan Dia adalah Dilanku Tahun I99I. Perbedaan kedua novel tersebut terletak pada latar waktu yang berbeda, namun memiliki cerita yang berkesinambungan. Alasan pengarang membagi kedua novel tersebut adalah ingin membaginya beberapa periode. Seperti yang dipaparkan secara langsung dalam novel, bahwa pengarang ingin membagi peristiwa yang dialami 
tokoh pada masing-masing kejadian. Misalnya, pada novel pertama menceritakan pendekatan tokoh Dilan dengan Milea sehingga resmi berpacaran sedangkan novel kedua berisikan kisah Dilan dan Milea dengan problema yang dihadapi saat mereka menjalin hubungan. Di samping itu, novel ini lebih memperlihatkan kenakalan remaja yang digambarkan tidak jauh berbeda dengan realitas kehidupan remaja pada saat sekarang ini.

Selain novel tersebut berisikan cerita yang berkesinambungan dan menggambarkan kenakalan remaja, ada alasan lain mengapa novel tersebut perlu dikaji dari segi potret kenakalan remaja. Seperti maraknya perbincangan di kalangan masyarakat Indonesia dan terjadinya berbagai kontroversi. Salah satu pertentangan tersebut adalah aksi unjuk rasa penolakan dari pihak Aliansi Mahasiswa Peduli Pendidikan Nasional yang mewarnai pemutaran film Dilan. Dilansir dari www.sulselsatu.com, demonstran itu menilai sejumlah adegan yang tidak patut dan melanggar hukum. Dengan hadirnya film tersebut, dikhawatirkan akan meningkatkan kekerasan dalam dunia pendidikan. Secara perspektif masyarakat yang menyalahkan filmnya, akan tetapi film tersebut merupakan film yang berangkat dari novel yang dijadikan sebagai objek penelitian ini, yaitu novel Dilan Dia adalah Dilanku karya Pidi Baiq. Cerita antara film dan novel tidak jauh berbeda, hanya saja cerita pada film sedikit ringkas dibanding dengan novel. Namun, kedua karya tersebut sama halnya memperlihatkan kenakalan remaja. Oleh sebab itu, tulisan ini hendak membahas bagaimana potret kenakalan remaja yang terdapat dalam novel tersebut, baik dari segi bentuk, penyebab, dan dampak kenakalan remaja.

Penelitian mengenai potret kenakalan remaja dalam novel Dilan Dia adalah Dilanku karya Pidi Baiq ini menitik beratkan pada realitas objektif. Sehingga pendekatan yang digunakan adalah pendekatan mimesis. Sebagaimana yang dikemukakan Abrams (dalam Muhardi dan Hasanuddin WS: 2006) bahwa pendekatan mimesis merupakan pendekatan yang menghubungkan karya sastra otonom dengan realitas objektif. Oleh sebab itu, menerapkan pendekatan mimesis dalam kajian sastra, dibutuhkan data-data denagn realitas yang ada di luar karya sastra. Secara definitif, Ratna (20I I) mengatakan teori sosiologi sastra adalah analisis, pembicaraan terhadap karya sastra dengan mempertimbangkan aspek-aspek dalam kemasyarakatannya. Sosiologi sastra bersifat luas karena mewadahi sebuah kemungkinan untuk melaukan anlaisis karya sekaligus dalam kaitannya dengan unsur-unsur intrinsik dan ekstrinsik, aspekaspek sosial yang terkandung dalam karya demikian juga sebagai aspek-aspek kemasyarakatan dengan latar belakang sosial proses kreatif.

Berdasarkan penulisan latar belakang yang telah dipaparkan, penelitian mengenai potret kenakalan remaja dalam novel Dilan Dia adalah Dilanku karya Pidi Baiq membahas tentang bagaimanakah bentuk, penyebab, dan dampak kenakalan remaja dalam novel. Penelitian ini ditujukan kepada pembaca bahwa karya sastra adalah cerminan kehidupan sosial yang digambarkan oleh pengarang dengan caranya sendiri. Penelitian ini dilakukan karena pentingnya data-data yang berkenaan dengan kenakalan remaja dan kaitannya dengan realitas kehidupan sekarang ini.

\section{Metode}

Jenis penelitian ini adalah penelitian kualitatif dengan menggunakan metode deskriptif. Moleong (2012) penelitian kualitatif adalah penelitian dengan tujuan untuk memahami segala fakta yang ada yang berkenaan dengan apa yang dialami oleh subjek penelitian secara holistik dan dengan cara deskripsi berupa kata-kata dan bahasa pada suatu konteks khusus yang alamiah dengan memanfaatkan berbagai metode ilmiah. Penelitian kualitatif seperti yang dikemukakan oleh Nazir (I985) bertujuan untuk membuat deskripsi gambaran secara sistematis, faktual, dan akurat terhadap suatu fakta yang akan diselidiki. Tulisan ini memaparkan dan mendeskripsikan tentang potret kenakalan remaja dalam novel Dilan Dia adalah Dilanku karya Pidi Baiq.

Data berupa kata, frasa, kalusa, atau kalimat yang mengindikasikan permasalahan kehidupan remaja berupa ucapan tokoh, tindakan tokoh, atau paparan narator dalam novel tersebut. Gambaran kenakalan remaja ditelusuri melalui unsur penokohan. Sebagaimana yang dikatakan Muhardi dan Hasanuddin WS (2006) mengatakan bahwa penokohan memuat soal penamaan, keadaan fisik, pemeranan, karakter, dan keadaan psikis. Sumber data penelitan in adalah novel Dilan Dia adalah Dilanku karya Pidi Baiq. Seperti yang dijelaskan pada latar belakang, bahwa novel ini terdiri dari dua bagian. Bagian pertama yaitu novel Dilan Dia adalah Dialnku Tahun 1990 sedangkan bagian kedua yaitu novel Dilan Dia adlaah Dilanku Tahun I99I karya Pidi Baiq. Teknik pengabsahan data menggunakan teknik triangulasi. Dengan cara teknik ini, peneliti bisa memeriksa kembali temuan yang didapatkan dengan membandingkan temuan tersebut dengan berbagai sumber, metode, atau teori yang ada (Moleong, 2012). Data dianalisis dengan cara menginventarisasi data, mengklasifikasi data, menginterpretasi data, dan menarik kesimpulan. 


\section{Hasil dan pembahasan}

Dewasa ini, masalah tindakan kekerasan yang dilakukan remaja mengundang perhatian berbagai pihak. Beragam perangai yang timbul ulah remaja sehingga menyita perhatian, dimulai dari tindakan yang hanya sekedar penganggu, tindakan pelanggarn hukum ringan, sampai dengan yang termasuk kategori pelanggaran berat. Salah satu bentuk kenakalan pada remaja adalah kenakalan yang bersifat berulang. Maksudnya, suatu kenakalan yang dimulai dengan perilaku antisosial atau agresif yang disinggu pada masa remaja atau bahkan sejak kanakkanak sehingga bersifat lanjut sampai dewasa. Remaja yang kerap menjadi sorotan masyarakat karena sangat mudah dipengaruhi oleh lingkungan sekitarnya. Remaja sering terlibat permasalahan sosial yang dianggap meyimpang dan tidak sewajarnya dilakukan. Dengan demikian, perilaku yang lahir dari remaja tersebut terjadi karena suatu bentuk pengabaian sosial, sehingga mengembangkan pemikiran yang salah atau bertingkah laku yang menyimpang adalah hal yang cenderung mereka lakukan. Sebagaimana Achlis (1992) mengatakan bahwa keberfungsian sosial merupakan kemampuan seseorang dalam melakukan tugas dan perannya selama berhubungan dalam situasi sosial tertentu seperti adanya hambatan atau halangan dalam menyatakan suatu nilai yang ada pada dirinya dalam memperoleh kebutuhan hidupnya. Oleh sebab itu, peran penting yang dimiliki dukungan sosial amat penting bagi remaja dalam melaksanakan tugas perkembangannya. Berinteraksi dengan sosial membuat perilaku remaja mudah terpengaruh atu mudah terbawa arus perilaku negatif dan menyebabkan munculnya kenakalan remaja.

Potret kenakalan remaja adalah gambaran sekelompok individu yang berperilaku menyimpang dari norma yang ada. Pada penelitian ini, membahas tentang bagaimana potret kenakalan remaja yang terdapat dalam novel Dilan Dia adalah Dilanku karya Pidi Baiq. Aspek yang dibahas pada penelitian ini disesuaikan dengan tujuan penelian yaitu mendeskripsikan (I) bentuk kenakalan remaja; (2) penyebab kenakalan remaja; dan (3) dampak kenakalan remaja yang terdapat dalam novel. Pada bentuk kenakalan remaja, teori yang digunakan untuk menemukan data adalah teori yang dikemukan oleh Jensen, karena teori tersebut lebih mewakili segala aspek dari kecenderungan remaja bertindak kenakalan yang terdapat dalam novel. Gambaran kenakalan remaja dari segi bentuk yang didapati dalam novel dapat dilihat pada bagan berikut.

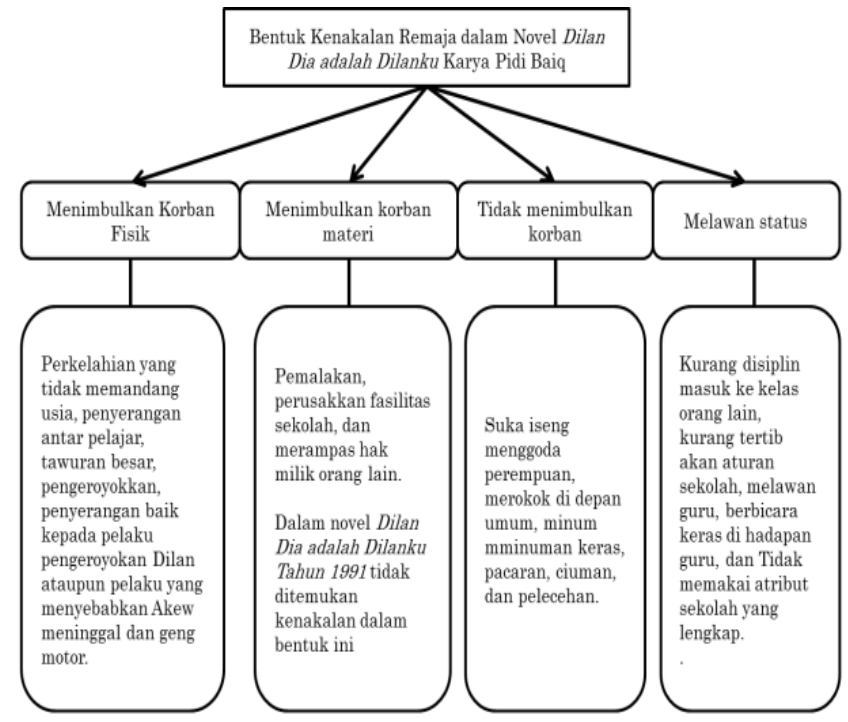

Bagan I. Kerangka Bentuk Kenakalan Remaja dalam Novel Dilan Dia adalah Dilanku karya Pidi Baiq

Bentuk kenakalan yang terdapat dalam novel ini cukup kompleks dengan sifatnya yang antisosial dan antimoral sehingga perspektif masyarakat yang berkenaan dengan kenakalan yang dilakukan oleh kalangan remaja bukanlah suatu kewajaran melainkan sudah melebihi batas kewajaran. Pada bentuk kenakalan yang menimbulkan korban fisik, sebagaimana yang diketahui bahwa kenakalan ini sangat banyak terjadi pada era sekarang. Banyak kenakalan yang melibatkan fisik seperti yang digambarkan dalam novel, antara lain perkelahian yang tidak memandang usia, penyerangan antar pelajar, tawuran besar, pengeroyokan, penyerangan baik kepada pelaku pengeroyokan Dilan ataupun pelaku yang menyebabkan Akew meninggal, serta geng motor. Namun, bentuk kenakalan yang paling fenomenal yang terdapat dalam novel tersebut dan mewakili seluruh bentuk kenakalan lainnya adalah geng motor. Geng motor menjadi suatu alasan penyebab terjadinya bentuk kenakalan lainnya yang dilakukan oleh remaja yang diceritakan. Misalnya, pembawaan negatif yang dilahirkan oleh geng motor hingga menyebabkan remaja cenderung bertindak kenakalan. Bentuk kenakalan remaja yang menimbulkan korban fisik yang terdapat dalam novel ini dapat dilihat pada kutipan berikut.

Dilan pernah berantem dengan anak kelas 3. Garagaranya disebabkan oleh karena orang itu bilang ke Dilan, yaitu pada waktu Dilan melewati mereka yang sedang nongkrong.

Si orang itu akhirnya berdiri untuk menatap mata Dilan. Dilan kemudian menghajarnya, dan terjadilan baku hantam.

Konon, diawali oleh adanya peristiwa itu, Dilan pernah dirawat di Rumah Sakit Boromeus. Dia masih ingat ia dirawat di Ruang Yosep kamar 
I520, dan koma selama satu hari akibat terkena tusukan diperutnya. Dicurigai berbagai balasan yang harus Dilan terima. Itu terjadi di daerah Jalan Merdeka (Baiq, 2015: 86).

Tampak bahwa Dilan terlibat perkelahian yang tidak memandang usia dengan melawan seniornya hingga menimbulkan korban fisik. Berawal dari perkara ejekan yang terlontar dari mulut seniornya dan membuat Dilan penasaran akan kenapa dia mengatakan hal yang kurang menyenangkan bagi pendengaran Dilan. Namun, karena emosi yang tidak terkendali oleh Dilan, Dilan menghajar seniornya dan terjadilah baku hantam. Apalagi, perkataan vulgar yang terucap oleh lawan Dilan yang membuat Dilan semakin geram dan emosinya tidak dapat dikontrol lagi. Akibatnya, Dilan harus menanggung resiko dari perkelahian tersebut berupa tusukan di perutnya karena berbagai balasan yang harus diterima Dilan dari seniornya. Di samping itu, Dilan juga mengalami koma selama satu hari di Rumah Sakit Boromeus.

Tidak jarang, ditemukan di lingkungan sosial tentang perkelahian yang berawal dari perkataan yang kurang menyenangkan, seperti kata makian, sumpah sera[ah atau kata yang menunjukan identitas buruk dari penuturnya. Jika dikaitkan dengan realitas sosial sekarang ini, kata tersebut sudah lumrah bagi kalangan remaja sebab kata tersebut sebagai simbol pengakraban diri. Akan tetapi, ada masanya kata tersebut sebagai pemicu emosi seseorang hingga menimbulkan kemarahan dan kekecewaan. Adapun bentuk kenakalan lainnya yang berkategorikan kenakalan yang menimbulkan korban fisik berupa pengeroyokkan. Seperti kutipan berikut ini.

Aku duduk mencoba mendapatkan lebih dekat dengan Dilan. Tanganku gemetar membersihkan bercak darah di mukanya.

"Berantem sama siapa?" "Atas dasar apa mengeroyok?” Itu adalah hal yang besar bagiku dan menakutkan meski Dilan bersikap sebagai hal biasa baginya".

Aku benar-benar ingin tahu siapa yang sudah ngeroyok Dilan, seolah-olah saat itu aku ingin segera membunuh pelakunya.

"Bi Eem, berantem sama siapa?" (Baiq, 2019: 82-83).

Pengeroyokkan mejadi momok ketakutan masyarakat karena tindakan tersebut termasuk tindakan pidana. Seperti yang dialami Dilan sebagai korban pengeroyokkan oleh segerombolan orang yang tidak dikenal. Berawal dari posisi Dilan yang lagi sendirian, dengan sontak datang empat orang yang tidak dikenal dan langsung menyerang Dilan. Sangat jelas, bahwa pengeroyokkan adalah salah satu bentuk kenakalan yang menimbulkan korban fisik.
Buktinya, yang diterima oleh Dilan dengan mengalami luka-luka di bagian wajahnya.

Pada realitas sosial remaja sekarang ini, pengeroyokkan dikenal dengan tindakan bullying secara fisik marak terjadi baik di kota-kota ataupun daerah. Baru ini, media massa kembali memberitakan kenakalan yang dilakukan remaja berupa tindakan bullying. Dilansir dari jatim.suara.com, seorang siswa SMP harus kehilangan jarinya akibat dikeroyok atau dibuli secara fisik oleh sekelompok siswa lainnya. Peristiwa ini terjadi pada 3 Februari 2020 di Kota Malang. Berdasarkan pengakuantujuh siswa terduga pelaku kekerasan tersebut, bahwa korban pernah dibanting ke paving dan pohon. Selain itu, beberapa hari setelah kejadian tersebut, tepatnya pada II Februari 2020 terjadi lagi kasus bullying yang dilakukan oleh tiga siswa laki-laki terhadap siswa perempuan. Kejadian tersebut berlangsung di Kecamatan Butuh, Kabupaten Purworejo, Jawa Tengah. Berdasarkan informasi solopos.com, kasus kekerasan tersebut berawal dari permasalahan dari ketiga tesangka yang meminta uang Rp. 2000 kepada korban. Kemudian korban melaporkan kepada guru dengan menambahkan nominal yang diminta ketiga tersangka tersebut menjadi Rp. 20.000. Oleh sebab itu, ketiga tersangka melakukan kekerasan fisik terhadap korban karena kesal dengan pengakuan yang menipu daya tersebut. Korban ditampar, dipukul, hingga ditendang. Berdasarkan hasil visum, korban mengalami lebam di pinggang sebelah kanan diduga akibat ditendang. Seperti yang dipaparkan Permatasari dan Azwar (2017) mengatakan bahwa pelaku bullying yang melakukan penyerangan memiliki motif dendam dan sakit hati karena perilaku korban sendiri. Hal tersebut terjadi pada Dilan yang dikeroyok oleh sekolompok orang yang pada akhirnya tahu sekelompok orang tersebut, yaitu Kakaknya Anhar. Kakaknya Anhar memiliki motif balas dendam karena ketidaksukaan Kakaknya Anhar terhadap Dilan yang telah memukuli adiknya secara bertubi-tubi hingga tidak berdaya.

Berikutnya kenakalan yang menimbulkan korban materi yang terdapat dalam novel. Dalam menentukan atau mengklasifikasikan data, peneliti menggunakan teori yang dikemukakan oleh B. Simadjuntak karena teori tersebut lebih mewakili seluruh aspek yang berkenaan faktor yang melatarbelakangi kenakalan remaja yang ada dalam novel. Namun, pada novel bagian kedua tidak didapati sama sekali bentuk kenakalan yang menimbulkan korban materi. Kenakalan yang menimbulkan korban materi yang didapatkan dalam novel berupa pemalakan, perusakan fasilitas sekolah, perampasan. Lihat kutipan berikut. 
Banyak orang yang ngomong pada gak suka ke Anhar katanya dia itu kurang ajar dan Troublemaker.

Konon, diam-diam, bersama Si Engkus, suka malakin anak-anak kelas I.

Anhar juga katanya pernah ditahan polisi karena melakukan tindakan kriminal, merampas barang orang dengan tindakan kekerasan di jalan raya. Melakukan kejahatan dan meresahkan masyarakat yang tidak bisa ditolerir (Baiq, 2015: 84).

Kenakalan ini menjadikan masyarakat sebagai objek dalam memperlancar tindakannya. Tindakan yang dilakukan Anhar menimbulkan kerugian bagi masyarakat berupa materi. Kutipan di atas, tampak bahwa Anhar digambarkan sebagai pribadi yang merampas hak milik orang lain dan pemerasan atau bisa disebut dengan pemalakan dengan tindakan kriminal. Sebagai akibatnya Anhar terlibat dengan pihak kepolisian karena perilaku Anhar menurut perspektif masyarakat tidak bisa untuk ditolerir. Jika dilihat pada era sekarang, kenakalan dalam bentukk ini marak terjadi, tidak terkecuali yang dilakukan oleh remaja. Bisa dikatakan, bahwa remaja kerap melakukan tindakan yang berbau negatif dan menyimpang dari norma yang ada.

Kenakalan sosial yang tidak menimbulkan korban di pihak orang lain dan digambarkan dalam novel berupa suka iseng menggoda perempuan, merokok di depan umum, minum-minuman keras, pacaran, pelecehan, serta ciuman juga marak terjadi pada relaitas sosial remaja sekarang ini. Lingkungan sosial memiliki peranan penting bagi kehidupan manusia. Namun, terkadang lingkungan dapat memberikan pola gaya hidup yang mempengaruhi sikap dan pola pikir seseorang menjadi buruk hingga cenderung melakukan perbuatan yang menjurus pada suatu kenakalan. Berikut kutipan yang menggambarkan perilaku kenakalan sosial yang tidak menimbulkan korban di pihak orang lain yang terdapat dalam novel.

"Sampai dicari-cari gitu", kata Susi nimbrung, kutangkap matanya mendelik ke arahku sambil mengembuskan asap rokoknya. Kukira dia tahu aku sedang memandangnya (Baiq, 2015: 308).

Susi adalah seorang pelajar yang bergender perempuan yang memiliki kebiasaan merokok. Diceritakan, bahwa Susi dengan santainya meghembuskan asap rokoknya di depan khalayak umum. Tentu saja hal ini melibatkan orang lain yang memberikan persepsi mengenai Susi yang berperangai kurang baik dan memiliki pergaulan bebas. Dilihat pada era sekarang, merokok juga dapat dilakukan dengan cara elektrik atau biasa disebut dengan vape. Kemajuan teknologi semakin pesat, yang membuat kemunculan vape di tengah masyarakat menjadi popular, terutama bagi kalangan remaja atau perokok aktif. Vape juga sama halnya dengan rokok yang bersifat adiktif nikotinl, yang berpotensi merusak paru-paru dengan mengandung bahan kimia yang digunakan sebagai penyedap. Perihal merokok, tentu saja membahayakan diri sendiri dan juga orang lain. Terutama pada perempuan, yang memiliki kebiasaan merokok sangat membahayakan kesehatannya, seperti meningkatnya semua jenis kanker terutama kanker payudara dan kanker serviks. Dengan demikian, merokok pada pelajar bisa dikatakan sebagai bentuk kenakalan sosial yang tidak menimbulkan korban di pihak orang lain.

Aspek terakhir, mengenai bentuk kenakalan remaja berupa kenakalan yang melawan status yang terdapat dalam novel ini sangat beragam. Persoalan kenakalan yang melawan status terutama mengingkari statusnya sebagai pelajar sangat menyita perhatian publik. Salah satunya bentuk kenakalan ini adalah melawan guru. Rosyid (2019) mengatakan bahwa salah satu yang mendorong murid melawan gurnya adalah sikap guru yang berlebihan terhadap murid sehingga merasa direndahkan. Pernyataan tersebut persis dengan yang digambarkan dalam novel. Lihat kutipan berikut.

Hari senin, pada saat upacara bendera, Dilan ikut upacara bendera, tapi dia masuk di barisanku. Berdiri sejajar denganku. Tentu saja itu melanggar peraturan. Harusnya, dia berada di barisan kawan-kawan sekelasnya.

Benar saja, tepat pada waktu Kepala Sekolah sedang pidato, Pak Suripto datang menegurnya. Tanpa kata-kata, Pak Suiprto langsung narik kerah belakang baju Dilan. Dia bermaksud narik Dilan untuk keluar dari barisan kelasku (Baiq, 2015: I66).

Berawal dari Dilan yang tidak bergabung dengan barisan dikelasnya melainkan bergabung di barisan kelas lain, yaitu kelasnya Milea. Kutipan ddi atas, menggambarkan pribadi Dilan yang kurang etika dalam melakukan tindakan. Persepsi sosial beranggapan bahwa Dilan melakukan tindakan secara amatir atau orang yang melakukan sesuatu atas dasar kesenangan saja. Dilan akhirnya ditegur oleh guru BP sekolahnya, namun diperlakukan dengan cara kasar yaitu dengan menarik kerah bajunya Dilan. Sehingga terjadi perlawanan guru yang dilakukan Dilan ditambah lagi guru BPnya tersebut menampar Dilan. Akibatnya emosi Dilan tidak bisa terkontrol lagi, Dilan menampar balik guru BPnya tersebut dan memukul secara bertubi sebelum guru BP tersebut menampar untuk kedua kalinya. Tentu saja hal tersebut dinilai sebagai kenakalan yang bertindak dengan melanggar statusnya sebagai pelajar.

Cukup banyak faktor yang mendorong remaja bertindak kenakalan. Kenakalan remaja sebagai suatu perilaku yang menyimpang atau melampaui batas 
toleransi orang lain yang berada di lingkungan sekitar remaja serta suatu tindakan yang dinilai menyimpang dari norma yang ada. Secara sosial, kenakalan remaja ini terjadi karena salah satu bentuk pengabaian sosial sehingga remaja cenderung melakukan kenakalan dan mengembangkan perilaku yang menyimpang. Sarwono (2012) mengatakan bahwa remaja terlibat dalam tindakan kenakalan adalah remaja yang kurang diawasi, dijaga, diberi bimbingan, dan diperhatikan oleh kalangan terutama oleh orangtua remaja itu sendiri. Oleh sebab itu, remaja cenderung melakukan tindakan yang bersifat brutal atau tindakan yang menyimpang dari aturan yang ada. Pada penelitian ini, peneliti menggunakan teori yang dikemukakan oleh B. Simadjuntak karena teori tersebut lebih mewakili seluruh aspek yang berkenaan dengan faktor yang mendorong remaja melakukan kenakalan yang ada dalam novel Dilan Dia adalah Dilanku karya Pidi Baiq.

Alasan kenapa remaja yang diceritakan dalam novel cenderung melakukan kenakalan disebabkan oleh dua faktor, yaitu yaitu faktor internal dan faktor eksternal. Pertama, faktor internal yang ditemukan dalam novel berupa pembawaan negatif yang mengarah pada perbuatan nakal, lemahnya kontrol diri dan persepsi sosial, ketidakmampuan penyesuaian diri terhadap perubahan lingkungan, dan ketidakadanya kegemaran yang kreatif pada diri remaja atau hobi yang sehat. Sedangkan faktor yang kedua, yaitu faktor eksternal yang ditemukan dalam novel berupa pengawasan yang kurang efektif dalam pembinaan,kuran pahaman terhadap permasalahan remaja, serta ketidaktahuan keluarga terhadap permasalahan keluarga. Berikut kutipan yang disertai analisis tentang mengapa remaja tersebut melakukan suatu kenakalan.

"Aku betul-betul jadi takut. Saat itu, aku berpikir Dilan pasti sangat nakal dan mungkin jahat. Meskipun aku yakin, dia tidak seperti yang kuduga” (Baiq, 2015: 32).

Kutipan di atas menggambarkan persepsi masyarakat sekitra tentang geng motor yang kerap melakukan tindakan yang berbau negatif. Sebab, geng motor dianggap sebagai suatu fenomena masalah sosial yang sangat erat kaitannya dengan kesulitan remaja dalam melakukan adaptasi. Diceritakan, bahwa identitas Dilan sedikit demi sedikit terkuak karena Milea terus menelusuri siapa yang berusaha mendekatinya. Milea tahu bahwa Dilan adalah panglima tempur dari geng motornya. Milea menjadi takut akan sosok Dilan dengan jabatannya sangat menggentarkan. Sebagimana yang diketahui, tidak jarang ditemukan geng motor yang kerap melakukan tindakan kriminalitas atau memiliki kebebasan dalam bertingkah. Oleh karena itu, tidak salah lagi jika geng motor dianggap suatu komunitas yang bertindak negatif dan hal tersebut membawa perbuatan Dilan tidak sungkannya mengarah dalam kenakalan remaja.

...sampai akhirnya Pak Atam tahu ada seseorang penyelundup.

"Kenapa di sini?"

Kawan-kawan sekelas memandang semua ke arah Dilan. Muka mereka seperti puas karena akhirnya Pak Atam tahu dan Menegurnya.

"Salah masuk".

Dilan beranjak dari duduknya dan pergi diringi tatapan Pak Atam yang tidak respek kepadanya (Baiq, 2015: 47).

Lemahnya kontrol diri yang membuat Dilan nekat masuk ke kelasnya Milea yang pada saat itu jam untuk mengikuti pelajaran selanjutnya sedang berlangsung. Diceritakan, bahwa tidak ada yang berani menegur atau mengusir Dilan ketika dia masuk ke kelasnya Milea. Nandan sebagai ketua kelasnya Milea ikut berdiam diri namun merasa terganggu akan kehadiran Dilan. Hal ini menggambarkan lemahnya persepsi sosial yang ditimbulkan oleh para siswa yang ada dalam kelasnya Milea. Seolah mereka tidak peduli dan tidak merasa terganggu akan kehadiran Dilan. Digambarkan dalam novel, bahwa Dilan adalah pribadi yang banyak orang tidak menyukainya, salah satu alasannya adalah Dilan sebagai seorang gengster. Perihal lemahnya kontrol diri, tampak dari kutipan di atas bahwa Dilan berani menagambil resiko atas dasar kesenangan. Dengan Dilan yang rela meninggalkan pelajaran demi menarik perhatian Milea. Bahkan, Dilan menganggap remeh akan usiran Pak Atam yang akhirnya tahu bahwa kelas yang sedang diduduki tengah didatangi anak kelas lain.

Besoknya, di sekolah, aku mendapat kabar dari Piyan, entah bagaimana Piyan tahu, katanya Dilan ditangkap oleh kepolisian karena semalam bersama kawan-kawannya menyerang satu kelompok orang yang dia diduga sebagai pelaku yang sudah menyebabkan Akew meninggal.

Piyan bilang, Dilan ditahan sebentar, Dilan ditahan sebentar untuk kemudian dibebaskan, sesuai yang diminta oleh ayahnya Dilan. Tapi, sebagai gantinya, Dilan dihukum oleh ayahnya dengan diusir dari rumahnya (Baiq, 2019: 295-296).

Dilan terlibat pihak kepolisian gegara Dilan dan kawan-kawannya melakukan tindakan penyerangan kepada sekelompok orang yang mereka duga sebagai pelaku pengeroyokan Akew sebagai temannya sehingga meninggal. Namun, penahanan Dilan oleh pihak kepolisian itu hanya sebentar karena sesuai yang diintruksikan Ayahnya ke pihak kepolisian. Akan tetapi, sebagai gantinya Dilan diusir 
oleh Ayahnya dari rumahnya karena perbuatan Dilan sudah melampaui batas. Hal tersebut menggambarkan bahwa faktor yang mendorong Dilan melakukan kesalahan adalah ketidaktahuan Ayahnya dalam menangani masalah yang dihadapi oleh Dilan. Ayahnya Dilan tidak peduli muasal Dilan melakukan penyerangan dan tetap menilai anaknya sudah melakukan sebuah kesalahan besar.

Remaja terkadang hanya mengerti tentang apa yang akan dilakukan tanpa memikirkan dampakapa yang bisa timbul dari yang mereka lakukan tersebut. Terlebih pada yang dilakukan remaja tersebut tidak bisa lagi disebut sebagai suatu kenakalan yang wajar atau kesalahan biasa. Dewasa ini, sudah tidak asing lagi mendengarkan remaja yang bertindak dengan mengabaikan sosial sehingga mereka melakukan tindakan atas dasar kesenangan saja. Dengan beragamnya bentuk kenakalan dalam novel yang telah dipaparkan sebelumnya, maka beragam juga dampak yang timbul ulah kenakalan tersebut. Apapun kenakalan yang pernah remaja lakukan, akan berdampak pada dirinya sendiri, keluarga, maupun masyarakat. Dapat dilihat pada grafik lingkaran berikut.

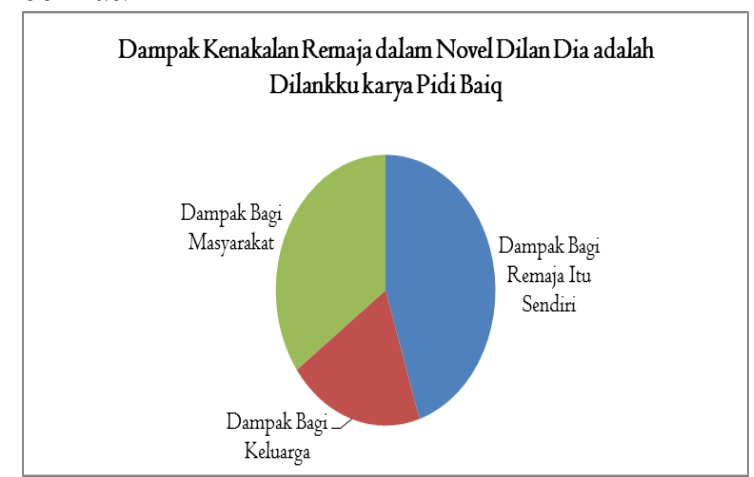

Grafik I. Dampak Kenakalan Remaja dalam Novel Dilan Dia adalah Dilanku karya Pidi Baiq

Berdasarkan temuan data yang terkumpul, bahwa dampak kenakalan yang paling dominan ditemukan dalam novel Dilan Dia adalah Dilanku karya Pidi Baiq adalah dampak bagi remaja itu sendiri seperti gambaran grafik di atas. Teori yang digunakan dalam menemukan data yang berkenaan dengan dampak kenakalan remaja adalah teori yang dipaparkan oleh Sumara dkk, karena teori tersebut lebih mewakili seluruh aspek yang berkaitan dengan dampak dari kenakalan yang dilakukan remaja yang diceritakan dalam novel. Pertama, dampak bagi remaja itu sendiri yang ditemukan dalam novel berupa koma akibat tusukan di perutnya Dilan, berbahaya bagi kesehatan akibat merokok, cedera fisik, pemecatan siswa dari pihak sekolah, nyawa melayang akibat geng motor, ditahan pihak kepolisian, dan teguran dari menteri pendidikan atau guru-guru sekolah akibat terlampau sering tidak memakai atribut sekolah yang lengkap. Berikut salah satu kutipan berupa dampak bagi remaja itu sendiri yang terdapat dalam novel.
"Lia Akew meninggal"
"Hah? Akew?"
"Iya"
"Akew meninggal? Serius?"
"Semalem"
"Kenapa?"
"Dikeroyok orang-orang yang gak dikenal"
Saat itu, aku khawatir bahwa Dilan terlibat di dalamnya. Aku berpikir bahwa itu sangat mungkin, mengingat Akew adalah orang satu kelompok dengan Dilan (Baiq, 2019: 284- 285).

Geng motor selain menimbulkan keresahan pada masyarakat juga menimbulkan resiko berupa korban fisik. Diceritakan, bahwa Akew meninggal gegara dikeroyok oleh sekelompok orang yang tidak dikenal dan diduga penyebab Akew meninggal karena ikutan geng motor. Sebagaimana, anggapan masyarakat tentang geng motor sebagai biang rusuh atau kerap membuat ulah hingga masyarakat risih akan kehadirannya. Eksitensi geng motor di mata masyarakat dianggap rendah dan selalu diperbincangkan tentang dampak yang bisa ditimbulkan akibat geng motor tersebut. Salah satunya berdampak bagi remaja itu sendiri, yang mengakibatkan nyawa melayang seperti yang telah ditanggung oleh Akew.

Beerikutnya dampak kenakalan remaja yang ditinjau dari segi keluarga yang ditemukan dalam novel berupa merasa malu dan kecewa yang dirasakan orangtua atas kesalahan yang dilakukan anaknya, perdebatan orangtua akibat permasalahan Dilan dan Anhar yang berkelahi gegara persoalan Milea yang ditampar oleh Anhar. Berikut salah satu kutipan berupa dampak bagi keluarga yang terdapat dalam novel.

"Pasti, lah, ada alasannya kenapa anak saya nampar. Gak mungkin, dong, langsung nampar gitu aja. Nah, gak tau kenapa tau-tau si Dilan, gak ngerti deh, kenapa dia ikut campur. Dia terus mukulin anak saya. Ya, mungkin cari perhatian atau apalah dari anak ibu. Gak ngerti saya".

"Cari perhatian gimana maksudnya?" tanya dengan nada yang geram.

"Atau gimanalah. Maksud saya, saudaranya Anhar itu kebanyakan polisi. Saya gak ada maksud mau sombong. Maksud saya kalau mereka tau, mereka bisa saja nyuruh saya nuntut anak ibu karena kata Anhar anak ibu yang mulai ngajak berantem. Bisa saja. Tapi, ya, gak usah, lah sampai segitunya, ya, Bu. Menurut saya, maksudnya masih bisa diselesaikan baik-baik” (Baiq, 2019: 205209).

Berawal dari Ibunya Anhar yang mempertanyakan mengapa Anhar menampar Milea. 
Sampai-sampai Ibunya Anhar melibatkan Dilan sebagai penyebab Anhar dipecat dari pihak sekolah. Muasal Dilan berkelahi dengan Anhar adalah karena Anhar menampar Milea. Akan tetapi, Ibunya Anhar tidak tahu bahwasannya Milea adalah perempuan yang disukai oleh Dilan. Oleh karena itu, Ibunya Anhar langsung menganggap Dilan sebagai orang yang hanya mencari perhatian dari Milea. Hal tersebut membuat Bundanya Dilan merasa geram, dengan perkataan Ibunya Anhar secara tidak langsung merendahkan keberadaan anaknya, Dilan. Sementara itu, secara tidak langsung Ibunya Anhar mengancam kepada Milea bahwa dia mempunyai banyak saudara polisi dan bisa saja untuk menuntut permasalahan ini. Sebagai akibat dari kesalahan yang dilakukan oleh Dilan dan Anhar adalah Ibunya Anhar berdebat dengan Bundanya Dilan tentang perbuatan yang telah Dilan, Anhar dan Milea lakukan.

Keterlibatan orangtua dalam tindakan kenakalan yang dilakukan remaja seperti aksi seorang emak yang mencari dan menyorakkan anaknya di keramaian para demonstran. Dilansir dari situs web www.suara.com, tentang seorang emak yang mencari anaknya sedang melakukan aksi demo di belakang Kantor Dewan Perwakilan Rakyat (DPR) Republik Indonesia, Jakarta. Kejadian tersebut membuat masyarakat terharu akan perhatian orangtuanya kepada anaknya dengan menyuruh anaknya tersebut pulang dan tidak melanjutkan aksi demo. Aksi demo yang dilakukan oleh anaknya pada tanggal 25 September 2019 tentang penolakan terhadap RUU KUHP yang dirancang oleh anggota DPR. Berdasarkan berita tersebut, tampak bahwa keterlibatan orangtua terhadap perbuatan yang mungkin membahayakan bagi anaknya. Sebagaimana yang diketahui, bahwa aksi demo pada saat itu memakan korban luka dan jiwa.

Aspek terakhir mengenai dampak kenakalan remaja dari segi masyarakat yang ditemukan dalam novel berupa kerisihan pada masyarakat terutama pada kalangan perempuan, anggapan buruk dari masyarakat sehingga perbuatan remaja tidak bisa ditolerir dan hal ini disebabkan oleh geng motor serta kekhawatiran masyarakat yang timbul gegara geng motor. Berikut salah satu kutipan berupa dampak bagi masyarakat yang terdapat dalam novel. Sekonyong-konyong kami mendengar raungan motor dari luar pagar sekolah. Raungan motor yang banyak dan ribut sekali disambut oleh siswa dan guru yang pada keluar dari tempatnya, termasuk aku, untuk ingin tahu ada apakah gerangan.

Terjadi hiruk pikuk tapi sekaligus seperti panik (Baiq, 20I5: I44).

Keributan yang dialami oleh guru beserta siswa lainnya bermula dari Anhar dan kawan-kawannya yang memalak anak sekolah lain. Namun tidak dapat apa yang diinginkan, dia memukul anak tersebut. Sehingga, terjadilah sebuah kerusuhan di sekolah yang tengah ditempati Anhar yaitu segerombolan geng motor berseragam sekolah berdatangan dengan tujuan untuk menyerang Anhar. Sebab, segerombolan geng motor tersebut diduga dari sekolah dimana anak yang dipukul tersebut bersekolah. Akibat dari incaran yang tidak didapati oleh penyerang tersebut, mereka menyerang dan merusak fasilitas sekolah dengan melempari sekolah menggunakan batu sehingga kaca kelas tepat di pintu gerbang sekolah pecah berkeping-keping. Di samping itu, kerusuhan yang terjadi dengan melibatkan guru dan siswa-siswa di sekolah tersebut merupakan bentuk dari dampak kenakalan remaja yang melibatkan masyarakat.

\section{Simpulan}

Novel Dilan Dia adalah Dilanku karya Pidi Baiq merupakan novel yang berisikan cerita tentang perjalanan antara dua remaja namun diselingi problema remaja yang bersifat kenakalan. Novel ini lebih memperlihatkan kenakalan remaja yang digambarkan tidak jauh berbeda dari realitas sosial remaja pada sekarang ini dan novel ini akan membuktikan bahwa karya sastra merupakan refleksi dari kehidupan nyata. Kebanyakan kenakalan remaja yang dilakukan disebabkan oleh faktor yang ditunjang oleh kemajuan teknologi di bidang informasi yang saat ini semakin pesat. Contohnya saja pada internet yang memberikan informasi dari berbagai belahan dunia dan munculnya stasiun telivisi dan luar negeri yang menyajikan film-film keras, sehingga menimbulkan dampak negatif bagi remaja, seperti tingkah laku agresif.

Berdasarkan hasil dan pembahasan, gambaran kenakalan remaja dalam novel ditinjau dari segi bentuk, penyebab, dan dampak. Pada bentuk kenakalan yang ditemukan berupa kenakalan yang menimbulkan korban fisik, kenakalan yang menimbulkan korban materi, kenakalan sosial yang tidak meniimbulkan korban, dan kenakalan yang melawan status. Dengan adanya bentuk kenakalan yang yang cukup kompleks, adapun faktor yang mendorong remaja melakukan kenakalan di balik bentuk kenakalan yang dipaparkan di atas. Faktor penyebabnya yaitu faktor internal dan faktor eksternal. Faktor internal seperti pembawaan negatif yang mengarah pada perbuatan nakal, lemahnya kontrol diri dan persepsi sosial, ketidakmampuan dalam penyesuaian diri terhadap perubahan lingkungan, tidak adanya kegemaran atau hobi yang sehat. Sedangkan faktor eksternal seperti pengawasan yang kurang efektif dalam pembinaan, kurangnya pemahaman terhadap remaja, dan ketidaktahuan keluarga dalam menangani masalah remaja. 
Berdasarkan bentuk dan faktor penyebab kenakalan remaja, tentu saja akan berdampak pada remaja berupa bagi remaja itu sendiri, bagi keluarga, dan bagi masyarakat.

Diperlukan tindakan-tindakan dari pihak yang berwajib dalam mengawasi atau memberikan pembinaan terhadap remaja di Indonesia sehingga bisa menurunkan kapasitas yang memuat kenakalan remaja serta kepada orangtua, diharapkan untuk menanamkan nilai moral, pendidikan dan religius kepada anak-anaknya, sehingga anak-anaknya lebih bisa mengontrol dirinya dari perilaku kenakalan remaja. Orangtua seharusnya lebih memperhatikan, memantau, mengawasi, dan membimbing anaknya agar perilaku anak terkontrol. Ketika remaja melakukan kesalahan, orangtua atau orang terdekat remaja harus mengetahui dan mampu memberikan teguran yang tidak membuat remaja tersebut merasa dipojokkan, merangkul agar mereka tidak merasa tidak pantas bergaul dengan yang lainnya, atau membimbing supaya mereka tidak hanya mendapatkan kehangatan saja, melainkan juga didikan.

\section{Persantunan}

Alhamdulillah, puji syukur kepada Allah Swt atas segala rahmat dan hidayah-Nya sehingga penulis dapat menyelesaikan penulis dapat menyelesaikan penelitian dengan judul "Potret Kenakalan Remaja dalam Novel Dilan Dia adalah Dilanku Karya Pidi Baiq. Penulisan penelitian ini tidak lepas dari bimibngan, bantuan, dan pengarahan dari berbagai pihak. Untuk itu, penulis mengucapkan kepada Dr. Yenni Hayati, S.S., M.Hum. yang telah meluangkan waktu, mengarahkan, dan memotivasi penulis dalam penulisan penelitian ini sehingga terselesaikan dengan baik. Teristimewa, kepada orangtua yang sangat penulis banggakan dan hormati yang kerap memberikan semangat dan mendoakan yang terbaik untuk penulis. Serta semua pihak yang telah membantu, baik secara langsung maupun tidak langsung yang tidak dapat disebutkan satu-persatu.

\section{Daftar Pustaka}

Achlis. 1992. Praktek Kerja Sosial I. Bandung: STKS.

Assegaf, Jaffar Shodiq. 2020. Miris, Viral Video Siswi SMP Ditendangi 3 Siswa di Dalam Kelas. (https://www.solopos.com/miris-viral-videosiswi-smp-ditendangi-3-siswa-di-dalam-kelasI046627, diakses 5 Februari 2020).

Baiq, Pidi. 20I4. Dilan Dia adalah Dilanku Tahun 1990. Bandung: Pastel Books.
2015. Dilan Dia adalah Dilanku Tahun I99I. Bandung: Pastel Books.

Damono, Sapardi Djoko. 1984. Sosiologi Sastra: Sebuah Pengantar Ringkas. Jakarta: Pusat Pembinaan dan Pengembangan Bahasa Departemen Pendidikan dan Kebudayaan.

Gunandha, Reza. 2019. Emak-Emak Cari Anaknya Yang Ikut Aksi Demo Di DPR. (https://www.suara.com/news/2019/09/25 /224940/emak-emak-cari-anaknya-yangdemo-di-dpr-faiz-pulang-nak, diakses 7 Januari 2020).

Hurlock, E.B. I991. Psikologi Perkembangan Suatu Pendekatan Sepanjang Rentang Kehidupan. Jakarta: Penerbit Erlangga.

Iswinarno, Chandra. 2020. Buntut Kasus Bullying, Kepala SMP I6 Malang Hingga Guru Bakal Disanksi.

(https://jatim.suara.com/read/2020/02/06/ I32325/buntut-kasus-bullying-kepala-smpI6-malang-hingga-guru-bakal-disanksi, diakses 5 Februari 2020).

Jamiluddin, Adon Nasrullah. 2017. Sosiologi Perkotaan. Bandung: Pustaka Setia Bandung.

Mappiwali, Hermawan. 2019. Demo Pemutaran Film Dilan I99I, Warga: Aneh Juga Ini Mahasiswa.

(https://www.sulselsatu.com/2019/03/01/ makassar/demo-pemutaran-film-dilan-I99Iwarga-aneh-juga-ini-mahasiswa.html, diakses 5 Februari 2020).

Moleong, Lexy J. 2012. Metodologi Penelitian Kualitatif. Bandung: Remaja Rosadakarya.

Muhardi dan Hasanuddin WS. 2006. Prosedur Analisis Fiksi. Padang: IKIP Padang Press.

Nazir. I985. Metode Penelitian. Jakarta: Ghalia Indonesia.

Ratna, Nyoman Kutha. 2010. Pardigma Sosiologi Sastra. Yogyakarta: Pustaka Pelajar.

Sarwono, Sarlito W. 2012. Psikologi Remaja. Jakarta: Rajawali Pers.

Sumara, Dadan dkk. 2017. "Gambaran Kenakalan Remaja dan Penanganannya”. Jurnal Penelitian \& PPM, 4(2), 129-389).

Welhendri dan Azwar. 2017. "Fenomena Bullying Siswa: Studi Tentang Motif Perilaku Bullying Di SMP Negeri OI Painan, Sumatera Barat". Jurnal Pengembangan Masyarakat Islam, IO(2), 333-367.

Wellek dan Warren. 20I4. Teori Kesusastraan. Jakarta: Gramedia

Rosyid. 2019. Apa yang membuat seorang siswa berani melawan guru? (https://id.quora.com/Apa-yang-membuatseorang-siswa-berani-melawan-guru, diakses 7 Februari 2020 
